\title{
SISTEM PENCARIAN PRODUK HALAL BERBASIS ANDROID PADA PUSAT KAJIAN PRODUK HALAL (PKPH) UNMA BANTEN MENGGUNAKAN METODE WATERFALL
}

\author{
Eka Ridwan Ruswandi ${ }^{1}$, Agung Sugiarto ${ }^{2}$, Zaenal Hakim ${ }^{3}$ \\ FTI Universitas Mathla'ul Anwar Banten, Jln. Raya Labuan KM.23, Cikaliung Saketi, \\ Pandeglang, Banten, Indonesia \\ Korespondensi author: agung.sugiarto@unmabanten.ac.id
}

\begin{abstract}
The Center for Halal Product Studies (PKPH) UNMA Banten is a center for the study of halal products located at Mathla'ul Anwar University, Banten, chaired by Hadi Susilo, S.Si., M.Si. (Faculty of Science and Pharmacy) and has been established since April 2017. Many halal and non-halal products are sold in the market, but there are only a few reliable sources that provide information about certified halal products, and nowadays information must be obtained quickly anywhere and anytime. With the creation of this halal product search system, it is hoped that it can overcome these problems because this system is built and used for android phones that can be carried and used at any time. The system is built using Sketchware, PHP, MariaDB Database and API.
\end{abstract}

Keywords: PKPH UNMA Banten; Products; Halal ; Android; Waterfall Method

Abstrak: Pusat Kajian Produk Halal (PKPH) UNMA Banten adalah sebuah lembaga pusat kajian produk halal yang berlokasi di Universitas Mathla'ul Anwar Banten di ketuai oleh Hadi Susilo, S.Si., M.Si. (Fakultas Sains dan Farmasi) dan sudah berdiri sejak April 2017. Produk halal dan tidak halal banyak dijual di pasaran, namun hanya sedikit sumber terpercaya yang menyediakan informasi tentang produk-produk halal yang sudah tersertifikasi, dan di masa sekarang informasi harus bisa didapat dengan cepat di mana saja dan kapan saja. Dengan dibuatnya sistem pencarian produk halal ini, diharapkan dapat mengatasi masalah-masalah tersebut karen sistem ini dibangun dan digunakan untuk ponsel android yang bisa dibawa dan digunakan kapan saja. Sistem dibuat menggunakan Sketchware, PHP, Database MariaDB dan API.

Kata Kunci: PKPH UNMA Banten; Produk; Halal; Android; Metode Waterfall

\section{PENDAHULUAN}

Di masa mendatang Pusat Kajian Produk Halal (PKPH) UNMA Banten juga dapat merekomendasikan pengajuan sertifikat produk halal untuk membantu masyarakat mendaftarkan dan menemukan produk-produk halal, seperti yang sudah tertera dalam UU JPH Pasal 67 ayat 1 yang berbunyi "Kewajiban bersertifikat halal bagi produk yang beredar dan diperdagangkan di wilayah Indonesia mulai berlaku lima tahun terhitung sejak UndangUndang ini diundangkan," .

PKPH UNMA Banten sudah memiliki sistem yang berjalan namun hanya digunakan untuk memuat informasi tentang kegiatan - kegiatan PKPH serta berita - berita islami saja, dan tidak menyediakan layanan pencarian produk halal, selama ini untuk mencari informasi 
produk halal yang sudah tersertifikasi, PKPH UNMA Banten harus menggunakan layanan pencarian dari website LPPOM MUI.

Dengan semakin majunya teknologi, informasi dapat dicari dengan mudah saat dibutuhkan, termasuk informasi produk halal yang sudah terserifikasi, Untuk menunjang dan mepublikasikan produk - produk halal tersebut maka perlu dibuatnya wadah untuk menampung informasi yang dapat diakses oleh masyarakat luas, dan sistem android adalah salah satu wadah yang cocok untuk hal tersebut. Android adalah sistem operasi berbasis linux yang dirancang untuk perangkat bergerak, perangkat android yang aktif setiap bulannya mencapai 2,5 milyar diseluruh dunia, hal tersebut sesuai untuk menjadikan sistem android sebagai wadah informasi yang dapat diakses masyarakat luas.

Tujuan dari penelitian ini adalah menghasilkan sistem yang dapat digunakan masyarakat luas untuk mencari informasi produk halal serta mengenalkan PKPH UNMA Banten kehalayak luas sebagai salah satu sumber terpercaya untuk mencari informasi produk halal.

Manfaat dari sistem ini adalah membuat sistem pencarian produk halal PKPH UNMA Banten yang bisa diakses masyarakat luas secara cepat dengan data informasi yang dapat dipercaya.

Sistem dapat didefinisikan sebagai kumpulan komponen-komponen yang bekerja sama untuk tujuan bersama. Misalnya bidang organisasi keuangan, operasi dan pemasaran memiliki tujuan yang sama untuk mencapai tujuan perusahaan secara keseluruhan. Hal ini dapat dilihat bahwa dalam sistem, data digunakan sebagai input untuk diproses yang menghasilkan informasi sebagai output.[1]

Android adalah sistem operasi bersifat open source berbasis Linux dirancang untuk perangkat seluler layar sentuh seperti telepon pintar dan komputer tablet. Android awalnya dikembangkan oleh Android, Inc., dengan dukungan finansial dari Google, yang kemudian membelinya pada tahun 2005. Sistem operasi ini dirilis secara resmi pada tahun 2007, bersamaan dengan didirikannya Open Ponsel Android pertama mulai dijual pada bulan Oktober 2008. Kemudian untuk mengembangkan Android, dibentuklah Open Handset Alliance yang merupakan konsorsium dari 34 perusahaan perangkat keras, perangkat lunak dan telekomunikasi.[2]

Pusat Kajian Produk Halal (PKPH) UNMA Banten adalah sebuah lembaga pusat kajian produk halal yang berlokasi di Gedung G , Universitas Mathla'ul Anwar Banten Jalan Raya Labuan Km 23 Saketi Pandeglang Banten dan sudah berdiri sejak 23 April 2017.

PKPH UNMA Banten yang di ketuai oleh Hadi Susilo, S.Si., M.Si. (Fakultas Sains dan Farmasi),memiliki visi menjadi pusat kajian halal terkemuka yang mendukung pengembangan produk halal di Indonesia dan global, dengan salah satu misinya adalah membantu UMKM dan perusahaan dalam mengurus sertifikat halal. [9]

JSON (JavaScript Object Notation) adalah format pertukaran data yang ringan, mudah dibaca dan ditulis oleh manusia, serta mudah diterjemahkan dan dibuat (generate) oleh komputer. Format ini dibuat berdasarkan bagian dari Bahasa Pemprograman JavaScript, 
Standar ECMA-262 Edisi ke-3 - Desember 1999. JSON merupakan format teks yang tidak bergantung pada bahasa pemprograman apapun karena menggunakan gaya bahasa yang umum digunakan oleh programmer keluarga $\mathrm{C}$ termasuk $\mathrm{C}, \mathrm{C}++, \mathrm{C} \#$, Java, JavaScript, Perl, Python dll. Oleh karena sifat-sifat tersebut, menjadikan JSON ideal sebagai bahasa pertukaran data.[3]

Application Progamming Interfac (API) adalah antarmuka yang digunakan untuk mengakses aplikasi atau layanan dari sebuah program. API memungkinkan pengembang untuk memakai fungsi yang sudah ada dari aplikasi lain sehingga tidak perlu membuat ulang dari awal. Pada konteks web, API merupakan pemanggilan fungsi lewat Hyper Text Transfer Protocol (HTTP) dan mendapatkan respon berupa Extensible Markup Language (XML) atau JavaScript Object Notation (JSON). JSON (Java Script Object Notation) adalah format pertukaran data yang ringan, mudah dibaca dan ditulis oleh manusia, serta mudah diterjemahkan dan dibuat (generated) oleh komputer [9]. Pemanggilan fungsi ke suatu situs tertentu akan menghasilkan respon yang berbeda kepada pengguna untuk membangun aplikasi enterprise di dalam websitenya.[4]

Sketchware adalah lingkungan pengembangan terintegrasi (IDE) berbasis pemrograman balok untuk mengembangkan aplikasi android, yang dijalankan di perangkat android itu sendiri. Aplikasi Sketchware dikembangkan oleh Scratch MIT.

Projek yang dihasilkan aplikasi sketchware kompatibel dengan Android Studio sebuah IDE yang digunkan di komputer, sehingga mempermudah pengembangan aplikasi android, Sketchware juga sudah mendukung liblary androidx.[7]

UML (Unified Modelling Language) adalah salah satu standar bahasa yang banyak digunakan di dunia industri untuk mendefinisikan requirement, membuat analisis dan desain, serta menggambarkan arsitektur dalam pemrograman berorientasi objek.[5]

\section{METODE}

Metode pengambilan data menggunakan metode (a)Wawancara, ini dilakukan dengan cara mengadakan komunikasi langsung dengan Direktur PKPH UNMA Banten yang dapat memberikan informasi serta data-data yang dibutuhkan untuk pembuatan sistem. (b)Pengamatan, penulis melakukan pengamatan langsung pada lokasi PKPH UNMA Banten yang menjadi objek penelitian. (c)Kepustakaan, pada tahap ini data dikumpulkan melalui berbagai literatur seperti pada buku, jurnal, ataupun dokumen yang didapat secara online ataupun offline berkaitan dengan penelitian ini. Hal ini bertujuan untuk mendapatkan data yang tidak ditemukan pada metode wawancara dan pengamatan. Selanjutnya data-data yang telah dikumpulkan akan digunakan untuk pembahasan materi.

Metode pengembangan sistem yang digunakan dalam pengembangan pada sistem ini adalah metode Waterfall, dengan tahapan (a)Kebutuhan, pada tahap ini penulis melakukan analisis pada Pusat Kajian Produk Halal (PKPH) UNMA Banten. Penulis mendengarkan dan menggali apa saja yang dibutuhkan oleh PKPH UNMA Banten. (b)Desain Sistem dan 
perangkat lunak, setelah menganalisis kebutuhan, penulis membuat rancangan dari sistem yang akan dikembangkan meliputi Use Case Diagram, Class Diagram, Activity Diagram, Sequence Diagram dan pembuatan interface dari sistem yang dikembangkan. (c)Penulisan Kode Program, penulis menerapkan desain yang telah dibuat. Use Case Diagram, Class Diagram, Activity Diagram, Sequence Diagram dan interface yang telah dibuat pada tahap desain, diterapkan dalam bahasa pemrograman. (d)Integrasi dan Pengujian Program, Sistem yang telah diimplementasikan dalam bahasa pemrograman diintegrasikan dan diuji kelayakannya. Pada tahap ini, penulis menggunakan black box testing untuk menguji sistem yang telah dikembangkan. (e)Operasi dan Pemeliharaan Program, pada tahap ini sistem sudah dapat dioperasikan oleh pengguna dan dilakukan pemeliharaan atau update apabila dibutuhkan.

\section{HASIL DAN PEMBAHASAN}

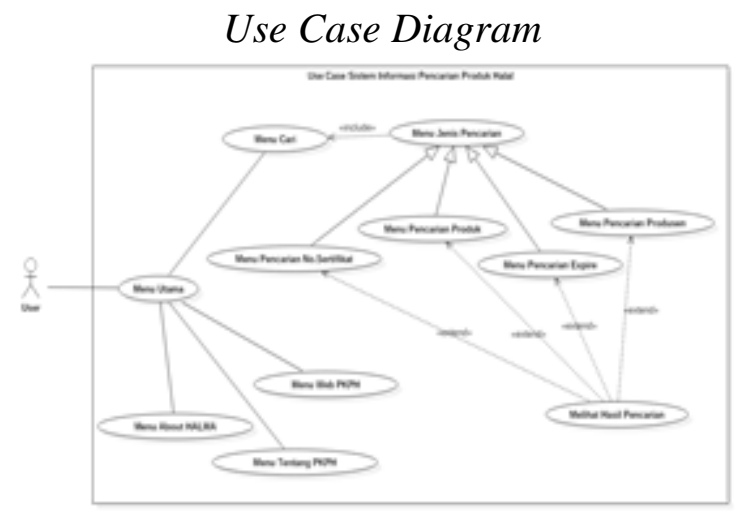

Gambar 1: Use Case Diagram

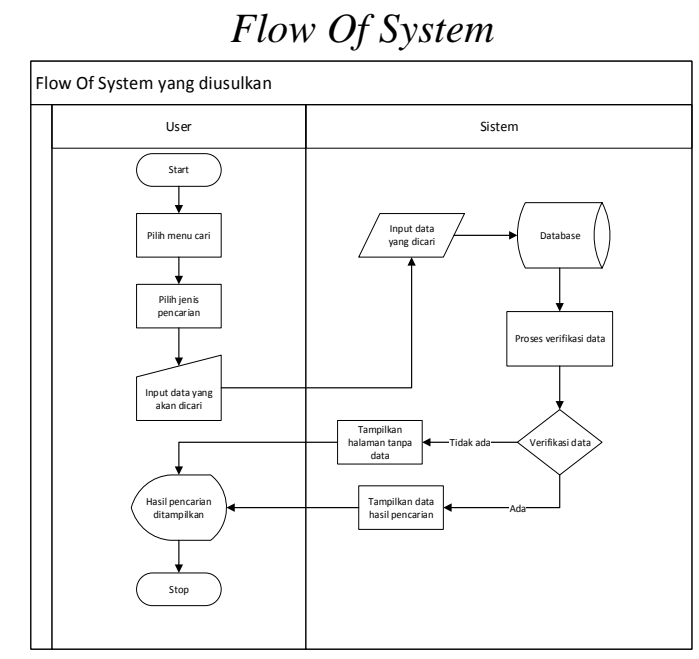

Gambar 2: Flow Of System (FOS) di Usulkan 
Tampilan Menu Pencarian

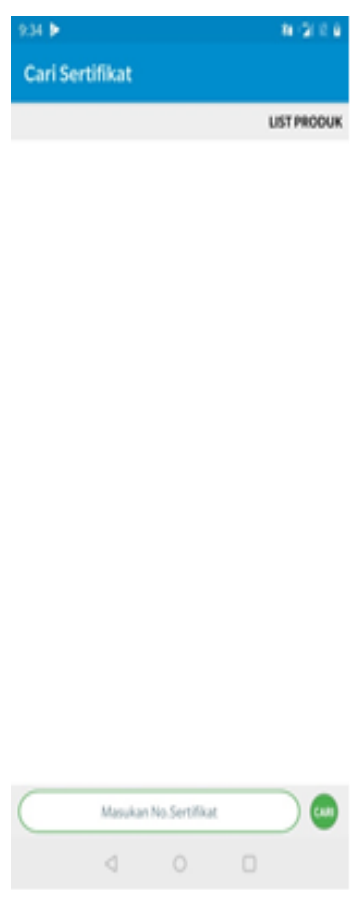

Gambar 3: Tampilan Menu Pencarian

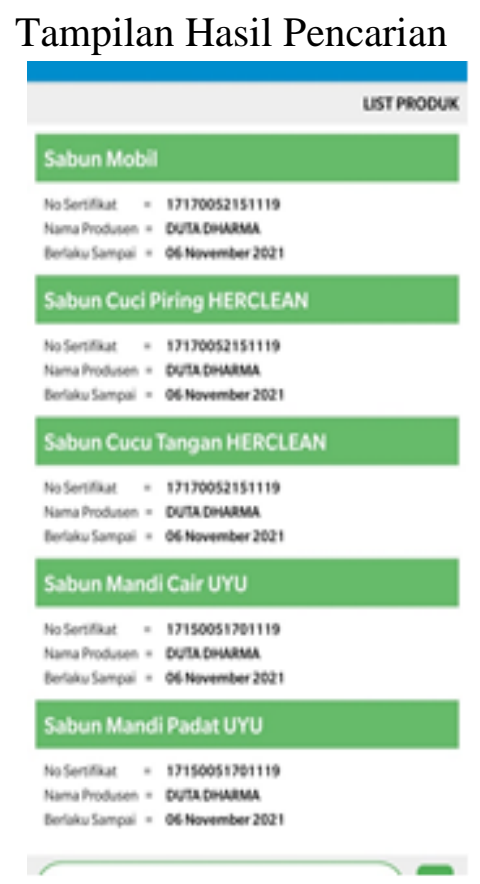

Gambar 4: Tampilan Hasil Pencarian 


\section{IJMA: International Journal Mathla'ul Anwar of Halal Issues \\ Volume 1 Nomor 1- Maret 2021}

Tabel I. Pengujian Black Box Input

\begin{tabular}{|c|c|c|c|}
\hline \multicolumn{4}{|c|}{ Kasus dan hasil (data diinput) } \\
\hline $\begin{array}{l}\text { Data yang } \\
\text { dimasukan }\end{array}$ & $\begin{array}{l}\text { Hasil yang } \\
\text { diharapkan }\end{array}$ & Pengamatan & Kesimpulan \\
\hline $\begin{array}{l}\text { Input data } \\
\text { yang akan } \\
\text { dicari pada } \\
\text { kolom } \\
\text { pencarian } \\
\text { sesuai jenis } \\
\text { pencarian } \\
\text { yang dipilih }\end{array}$ & $\begin{array}{l}\text { Sistem } \\
\text { memperose } \\
\text { data yang } \\
\text { diinput dan } \\
\text { menampilkan } \\
\text { hasil } \\
\text { pencarian }\end{array}$ & $\begin{array}{l}\text { Menampilkan } \\
\text { hasil } \\
\text { pencarian }\end{array}$ & $\begin{array}{l}\text { [x] Berhasil } \\
\text { [ ] Gagal }\end{array}$ \\
\hline \multicolumn{4}{|c|}{ Kasus dan hasil (data tidak diinput) } \\
\hline $\begin{array}{l}\text { kolom } \\
\text { pencarian } \\
\text { dikosongkan }\end{array}$ & $\begin{array}{l}\text { Sistem } \\
\text { menampilkan } \\
\text { pemberitahuan } \\
\text { untuk mengisi } \\
\text { kolom } \\
\text { pencarian }\end{array}$ & $\begin{array}{l}\text { Menampilkan } \\
\text { pemberitahuan }\end{array}$ & $\begin{array}{l}\text { [x] Berhasil } \\
\text { [ ] Gagal }\end{array}$ \\
\hline
\end{tabular}

Tabel II. Pengujian Black Box Output

\begin{tabular}{|c|c|c|c|}
\hline \multicolumn{4}{|c|}{ Kasus dan hasil (data ada pada database) } \\
\hline $\begin{array}{l}\text { Data yang } \\
\text { dicari }\end{array}$ & $\begin{array}{l}\text { Hasil yang } \\
\text { diharapkan }\end{array}$ & Pengamatan & Kesimpulan \\
\hline $\begin{array}{l}\text { Data yang } \\
\text { dicari ada } \\
\text { pada } \\
\text { database }\end{array}$ & $\begin{array}{l}\text { Sistem } \\
\text { mencari data } \\
\text { yang dicari } \\
\text { dan } \\
\text { menampilkan } \\
\text { data yang } \\
\text { dicari }\end{array}$ & $\begin{array}{l}\text { Menampilkan } \\
\text { data yang } \\
\text { dicari }\end{array}$ & $\begin{array}{l}\text { [x] Berhasil } \\
\text { [ ] Gagal }\end{array}$ \\
\hline \multicolumn{4}{|c|}{ Kasus dan hasil (data tidak ada pada database) } \\
\hline $\begin{array}{l}\text { Data yang } \\
\text { dicari tidak } \\
\text { ada pada } \\
\text { database }\end{array}$ & $\begin{array}{l}\text { Sistem tidak } \\
\text { menampilkan } \\
\text { data }\end{array}$ & $\begin{array}{lr}\text { Tidak ada } \\
\text { data yang } \\
\text { ditampilkan }\end{array}$ & $\begin{array}{l}\text { [x] Berhasil } \\
\text { [ ] Gagal }\end{array}$ \\
\hline
\end{tabular}


Hasil dari penelitian ini mebuktikan bahwa dengan menggabungkan kemajuan teknologi dan data terpercaya dapat diimplementasikan menjadi sebuah sistem yang dapat membantu untuk mencari informasi produk-produk halal yang sudah tersertifikasi dan tentu informasi yang didapat adalah informasi dari lembaga terpercaya.

Banyak sistem serupa namun semuanya menggunakan database yang sama, berbeda dari sistem serupa, sistem yang dibuat dalam penelitian ini menggunakan database sendiri, namun data yang digunakan adalah data yang didapat dari lembaga yang sama dengan sistem-sistem yang lain tanpa mengubah data yang didapat.

Kendati demikian data yang dimasukan pada database sistem ini tidak sama persis dengan sistem-sistem yang lain, hal tersebut dikarenakan banyaknya data yang ada memberikan keluasan dalam memilih dan memasukan data pada database, dan kebanyakan data yang dimasukan pada sistem ini adalah data produk-produk dari UMKM yang tidak ada/tidak dimasukan pada database sistem-sistem yang lain.

Sistem dalam penelitian ini dibuat langsung di ponsel android dengan menggunakan sketchware yang dapat memungkinkan pembuatan sistem berjalan efektif dan efisien, karena tidak membutuhkan perangkat yang memiliki spesifikasi yang tinggi untuk membuat dan menjalankan sistem, dengan demikian sistem yang dibuat dapat langsung di jalankan di perangkat andoid tersebut serta diubah dalam waktu yang singkat, data mentah pembuatan sistem bisa langsung dikirim pada perangkat andoid lain bahkan dapat dikirim pada perangkat komputer yang memungkinkan perangkat tersebut dapat mengubah sistem.

\section{KESIMPULAN}

Dari penelitian yang penulis lakukan di Pusat Kajian Produk Halal (PKPH) UNMA Banten, dapat diambil kesimpulan bahwa, dengan sistem yang dibuat dan dijalankan pada sistem operasi android ini dapat digunakan masyarakat serta dengan adanya sistem ini, Pusat Kajian Produk Halal (PKPH) UNMA Banten dapat dikenal masyarakat luas sebagai salah satu sumber terpercaya penyedia infromasi produk halal.

\section{DAFTAR PUSTAKA}

[1]Adhawiyah, Yunita. dkk. (2017). Rancang Bangun Sistem Informasi Penilaian Kinerja Pegawai Menggunakan Metode Psycological Appraisal (Studikasus :Kantor Wilayah Kementerian Agama Dki Jakarta). Studia Informatika: Jurnal Sistem Informasi. 10(2), 119126.

[2]Qibtiyah, U.M. dan Samirah R. (2017). Implementasi JSON Web Service pada Aplikasi Digital Library Politeknik Sukabumi. Jurnal Teknologi Rekayasa. JTERA, Vol. 2, No. 1 (Juni), p.9-16. 
[3]Herdiana, Yana. (2014). APLIKASI RUMUS MATEMATIKA SMA BERBASIS MOBILE. Jurnal Ilmiah Komputer dan Informatika, KOMPUTA, (Februari), p.1-8.

[4]Surahman, S. dan Eko B.S. (2017). Aplikasi Mobile Driver Online Berbasis Android Untuk Perusahaan Rental Kendaraan. ULTIMA InfoSys, Vol. VIII, No. 1 (Juni), p.35-42.

[5]Hendini, Ade. (2016) Pemodelan Uml Sistem Informasi Monitoring Penjualan Dan Stok Barang (Studi Kasus: Distro Zhezha Pontianak). Jurnal Khatulistiwa Informatika. Vol.IV, No.2 (Desember), p.107-116.

[6]Firly, N. (2019). Android Application Development for Rookies with Database. PT Alex Media Komputindo. Jakarta, 1-10.

[7]Sketchware, (2016). Sketchware - IDE In Your Pocket, Diakses pada 12 Mei 2020, dari http://sketchware.io/.

[8]Sugiarto, Agung. (2018). Sistem Informasi Pelayanan Administrasi pada Desa Ramaya Kecamatan Menes dengan Metode Waterfall. Seminar Nasional Rekayasa Teknologi Informasi. SNARTISI, Vol. I (November), p.99-103.

[9]PKPH UNMA Banten, (2017). Pusat Kajian Produk Halal Universitas Mathla'ul Anwar Banten, Diakses pada 12 Mei 2020, dari www.halalunmabanten.id.

[10]Wibowo, G.I. dkk. (2014). Perancangan Aplikasi Gudang Pada PT. Pakan Ternak Sejati. E-Journal Teknik Elektro dan Komputer. 